\title{
CONSUMERS' PERCEPTION TOWARD BRAND PREFERENCES WHILE PURCHASING PERSONAL CARE PRODUCTS: A STUDY ON RAJSHAHI CITY
}

\author{
ANIMA KARMAKAR ${ }^{1 *}$ \\ ATIA AHMED ${ }^{2}$
${ }^{1 *}$ Lecturer, Department of Business Administration, Varendra University, Rajshahi, Bangladesh ${ }^{2}$ Assistant Professor, Department of Business Administration, Varendra University, Rajshahi, Bangladesh \\ * (anima.karmakar67@gmail.com) \\ This journal is licensed under a Creative Commons Attribution-NonCommercial 4.0 International License (CC-BY-NC). \\ Articles can be read and shared for noncommercial purposes under the following conditions: \\ - BY: Attribution must be given to the original source (Attribution) \\ - NC: Works may not be used for commercial purposes (Noncommercial) \\ This license lets others remix, tweak, and build upon your work non-commercially, and although their new works must \\ also acknowledge you and be non-commercial, they don't have to license their derivative works on the same terms. \\ License Deed Link: http://creativecommons.org/licenses/by-nc/4.0/ \\ Legal Code Link: $h$ ttp://creativecommons.org/licenses/by-nc/4.0/legalcode \\ $A B C$ Research Alert uses the CC BY-NC to protect the author's work from misuse.
}

\section{Abstract}

This study conducted to focus the consumers' perception of international brand over local brand while purchasing personal care products. Consumers' perception highlighted on customer's psychology that determines their viewing attitude towards using the local or international brand.

Globalization makes the foreign trade easier than before and the availability of international brands confused the consumers' ethnocentrism towards local brand but it is also true that using too much foreign products can destroy the employment opportunity of local people and also the country may face of security issues from foreigners.

To examine the topic a convenient sampling method was applied to collect response from 280 customers from which 268 found free from errors; those respondents were used for the final study. The findings highlighted some factors that influence customers' perception toward choosing brand while purchasing personal care products. Data were collected from local customer of new market and Shaheb Bazar area of Rajshahi city.

Study reveals that according to the perception of the customer, product quality of local brands, price consideration, country of origin, availability of foreign brands and promotional actions have a significant role toward customer mind while purchasing products.

Moreover the findings suggest that, for the wellbeing of the society, local products need foremost priority to expand their business. as it is known that more demand of local products lead more production that create more job opportunity in the market and to build the country as self-sufficient, a customer focused local market should be enhanced.

The major contribution of the current study is that it focuses consumer's observation and suggestion to create more opportunities for local brand in market place.

Keywords

Brand, Local and International Brand, Customer, Perception

\section{INTRODUCTION}

It's a common phenomenon to ask a seller whether a product is local or foreign brand. Customer psychology always searches foreign goods as it indicates a good quality and a symbol 
of status. Although a foreign brand product charges high than local brand but advertisements and other issues make the preference high for consuming non local brand.

Customer perception toward products depends on several issues. Schiffman L.G. and Kanuk L.L., (2007) clarified that Consumers' perception gone through in three processes and these are selection, organization, and interpretation. Selection depends on Selective Exposure and Selective Attention whereas Consumers actively seek out messages that are pleasant, sympathize and Reassure customer of good purchases and also the message and medium to provide information are in a different way. Consumer organized their stimuli of product through figure and ground of advertisement and tends to group together objects that share the same physical characteristics and perceive an incomplete picture as a complete. Consumer interprets the stimuli through Physical Appearances, First Impressions and halo effect of the product.

Keller's Brand Equity Model focuses the customer's thinking and feeling about the product to build brand equity. Positive thoughts, feelings, beliefs, opinion create a positive perception toward the brand that creates strong brand equity which turned the customer to buy more and recommended to other people for purchasing those products.

On the other side in international market Globalization makes it easy to facilitate different branded product across the world. It is very interesting that some brands are too mush accepted in foreign countries than home country. For example Amway corp.an American company has more market share in Japan than USA. There are lots of examples where brands have more market share and high growth rate in foreign countries than home countries. Consumer psychology plays a vital role to make ground for choosing a foreign brand and here consumer psychology influenced by several factors such as quality, price, country of origin, promotional activities and so on. Brand has a strong and positive effect on customer mind through product name, logo, color, country, advertisement, social work and so on.

Bangladesh, a market based economy allow foreign brands available in the local market that create a barrier for local brand to expand and capture customer in a competitive way. Though many foreign companies follow planned domestication where local company jointly doing the business and as a result more production and manufacturing create more jobs but a large amount of profit back to the home country. A strict trade barrier can give opportunity to the local company to expand market share but in global market customer preference and acceptance is the key factor to survive in the market. Today's customers are more aware about purchasing any product and service. A wide range of advertisement tools capture the black box of customer, beside this social media force a person directly and indirectly to accept or reject any brands whether it is local or foreign.

In this age of globalization consumers have numerous options to drive their purchase decision. Madahi and Sukati (2012) describe that the purchase intention has become complicated and significant in recent era. The purchasing process to buy a particular brand or product is affected by various factors such as price of the product, design, packaging, knowledge about product, quality, celebrity endorsement, fashion and sometimes family relation as well (Shafiq et al., 2011). In our study we have attempted to identify the items that consumers give importance at 
the time of making a purchase decision. Respondents were questioned about the level of importance they lay on quality, price, availability, country of origin and advertisement.

\section{OBJECTIVES}

The objective of this study is to analysis the customer perception about foreign and local brand while purchasing personal care product. To conduct this study we included a part of questionnaires' where customer responded different types of brand name that they use as personal care products such as soap, washing powder or detergent, toothpaste, oil, shampoo etc.

Besides this find out some marketing strategy that can change perception toward the local brand.

\section{LITERATURE REVIEW}

Brand name, logo, media, advertising ,packaging ,warning labels ,retail strategy, shelf position works as a stimuli to create a sense towards a product and service.(Hawkins at al. (2011). Haque et al., (2015) conducted a research on Bangladeshi consumer of two major cities and found that $\mathrm{COO}$, brand image, the quality factor of foreign products has a significant positive effect of purchasing foreign products while ethnocentrism and religious factor has a negative effect on an intention of purchasing foreign products. The study suggests that image advertising needed to influence customer on buying local products.

Zareei A. and Ashtiani P.G.,(2014) conducted a research on consumer perception of global and local brands in Tehran, Iran and found that offering the same quality and price customer prefer international brands over local brands and moreover young generation has a tendency to purchase foreign branded products to avoid inferiority complexity. The study also reveals that people are ready to buy local brand products if international or foreign brand product is not available in the market. Ha J. and Lee k. (2012) point out that Judgment of foreign products is affected by positive $\mathrm{COO}$, negative ethnocentrism, and negative animosity while $\mathrm{COO}$ is influenced by the positive effect of halo and stereotype criteria of products.

Young Pakistani consumer's preferences of the global brand over local ones conducted by Ismail et al. (2012) revealed that product quality, price, COO, social- status, fashion, and ethnocentrism plays the significant role to purchase decision of consumers. Consumers pay little concern on Country of Origin and ethnocentrism otherwise all the above factors positively effect on consumer's mind to purchase foreign products.

In a study, Karmoker et al., (2016) identified that pricing strategy put a significant effect on customer mind as the customer think using foreign products they get the best benefit within least cost.

A study on customer perceptions in buying decisions toward Bangladeshi local apparel products shows that customer prefers brand based on quality, price, colors, design, the location of the shops, salesman courtesy, various offers and discount and so on. Conducting the study among 200 respondents study reveals some important factors influenced on customer's perception toward choosing branded clothes while purchasing and these are offers and discount, attractive range of color and designs, reasonable product price, the frequency of advertisement in print and electronic media and the attractiveness of advertisements. Islam et al.(2014). 
Babu (2004) found that TV advertisement and celebrity endorsement attract customer m more to recall the message regarding the brand very rapidly and female consumers feel confident tsao buy the product when they catch positive word of mouth of the product.

In developing countries, foreign products especially comes from the west have a "halo effect" on consumers that's why they prefer the nonlocal brand, not for the quality but also social status. (Batra et al.,2000).

Kramolis Jan and Drabkova Martain (2012) referred that Product placement is appropriate for B2C marketing and survey reveals that automobiles, consumer electronics such as laptops and mobiles as well as alcoholic beverages using this marketing techniques not only to persuade the viewer to buy the product directly but also to build brand positioning in the customer mind.

A study on local brand conducted by Islam et.al., (2014) found that customer considers the brand image, cost and commitment \& customer relationship as foremost factors while purchasing toiletries products. The brand image of the product depends on some variables like positive feelings, trustworthiness, great faith, promotional campaign \& brand communication. A study reveals that building strong customer relationship and acquiring more self-space in the retail shop attract customer toward purchasing the local product.

In general, people are interested to purchase foreign products regardless of their country. Roth et al. (2008) conducted a research to find a relationship between country of origin image (COI) and consumer brand equity (CBE) of Spain. Analyzing the data of 322 sample result revealed that $\mathrm{CBE}$ was shown to fully mediate the relationship between COI perceptions and consumer preferences where it clearly indicates that COI did not have a direct significant influence on consumer's product preferences.

Mollah et al. (2015) conducting a study on Bangladeshi consumer attitude toward different shampoo brand and find out that customer prefers more attribute in the product within the minimum price.

To increase the shareholder value and run the business process smoothly the integration of marketing process must need where product development management, supply chain management, and customer relationship management stands for the core business processes that generate value for customers(Srivastava et al.1999).

\section{METHODOLOGY}

\section{Population and Sample}

The population comprise of local customer based in Rajshahi city and from the population through convenient sampling 280 customers was chosen. Among the responses 12 got rejected as these were not properly filled-up. The rest of the 268 responses have been taken for analysis.

\section{Data Collection}

For data collection purpose a face to face interview was conducted with the respondents. They were asked a number of questions about their brand preference while purchasing personal care products. 
Time duration of the field review was September 2018 to December 2018.

\section{Data Analysis and Results}

A questionnaire was developed containing 7 questions concerning consumers' expectations and perceptions about the international brand over local brand. In the questionnaire five point Likert scale was used other than the demographic and important factors related questions.

Collected data has been tabulated and analyzed using MS Excel graphs and SPSS software. Some further analysis has also been done which encompassed describing and interpreting, after analyzing the data findings have been presented the form of tables, graphs, charts and frequencies.

\section{Data Demonstration}

This study designs the findings and analysis part in three patterns. The first part is demographic segmentation.The second pattern emphasized on the customer importance level of five items such as Quality, price, availability, country of origin and advertisement which developed by the literature review and the third part concern about customer perception towards local or foreign brand regarding these five items.

\section{FINDINGS \& ANALYSIS}

\section{Part A: Demographic Segmentation}

Demographic segmentation of this study focuses on age, gender, occupation, income level and the shopping pattern of respondents.

\begin{tabular}{|c|l|c|c|}
\hline Variable & \multicolumn{1}{|c|}{ Class } & Frequency & Percentages \\
\hline \multirow{4}{*}{ Age } & $15-20$ & 44 & $16.42 \%$ \\
\cline { 2 - 4 } & $21-25$ & 167 & $62.31 \%$ \\
\cline { 2 - 4 } & $26-30$ & 41 & $15.30 \%$ \\
\cline { 2 - 4 } & $31-40$ & 9 & $3.36 \%$ \\
\cline { 2 - 4 } & Above 40 & 7 & $2.61 \%$ \\
\hline \multirow{4}{*}{ Gender } & Male & 152 & $56.72 \%$ \\
\cline { 2 - 4 } & Female & 116 & $43.28 \%$ \\
\hline \multirow{5}{*}{ Income Level } & Student & 223 & $83.21 \%$ \\
\cline { 2 - 4 } & Housewife & 14 & $5.22 \%$ \\
\cline { 2 - 4 } & Businessmen & 13 & $4.85 \%$ \\
\cline { 2 - 4 } & Service Holder & 15 & $5.60 \%$ \\
\cline { 2 - 4 } & Others & 3 & $1.12 \%$ \\
\cline { 2 - 4 } & $5,000-15,000$ & 229 & $85.45 \%$ \\
\cline { 2 - 4 } & $16,000-25,000$ & 16 & $5.97 \%$ \\
\cline { 2 - 4 } & $26,000-35,000$ & 14 & $5.22 \%$ \\
\cline { 2 - 4 } & $36,000-45,000$ & 4 & $1.49 \%$ \\
\cline { 2 - 4 } & $45,000-45,000+$ & 5 & $1.87 \%$ \\
\hline Shopping Pattern & Online & 10 & $3.73 \%$ \\
\hline & Traditional & 258 & $96.27 \%$ \\
\hline
\end{tabular}

\section{Part B: Level of Importance}

To determine the level of importance, five items such as Quality, price, availability, country of origin and advertisement have been analyzed while customers purchasing personal care products. 


\section{Quality:}

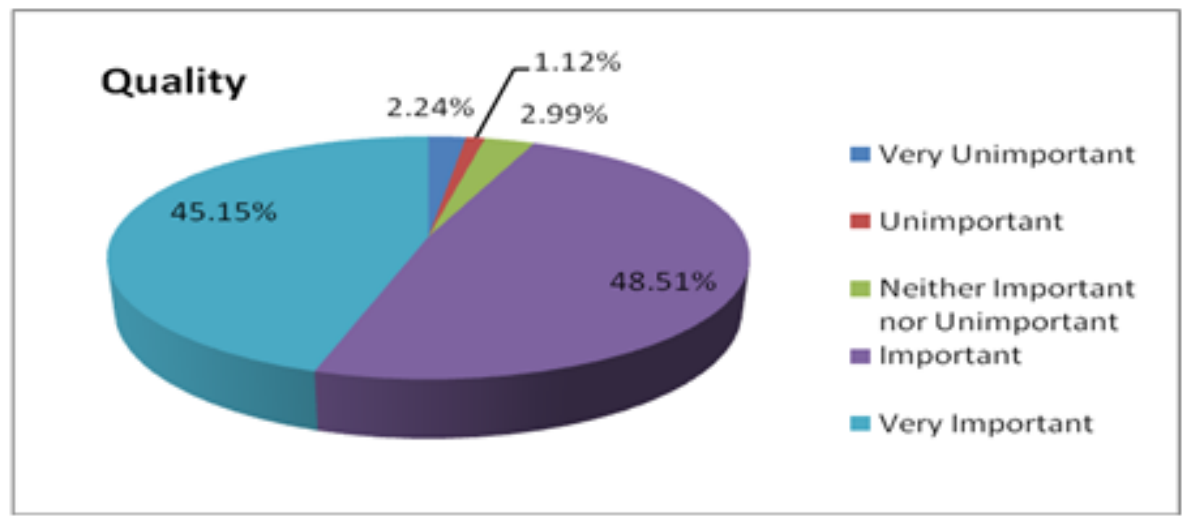

Figure 1: Priority Level on Quality

Quality refers to how good something is compared to other similar things. It is very crucial item for creating customer satisfaction and to maintain them. Our research reveals the same fact that quality has huge significance to the customers at the time of making a purchase decision. $45.15 \%$ of our total respondents consider quality as very important and $48.51 \%$ consider it as important in case of purchasing personal care product. The mean value of 4.3321 also supports that most of the consumer put emphasis on the quality of product.

\section{Price:}

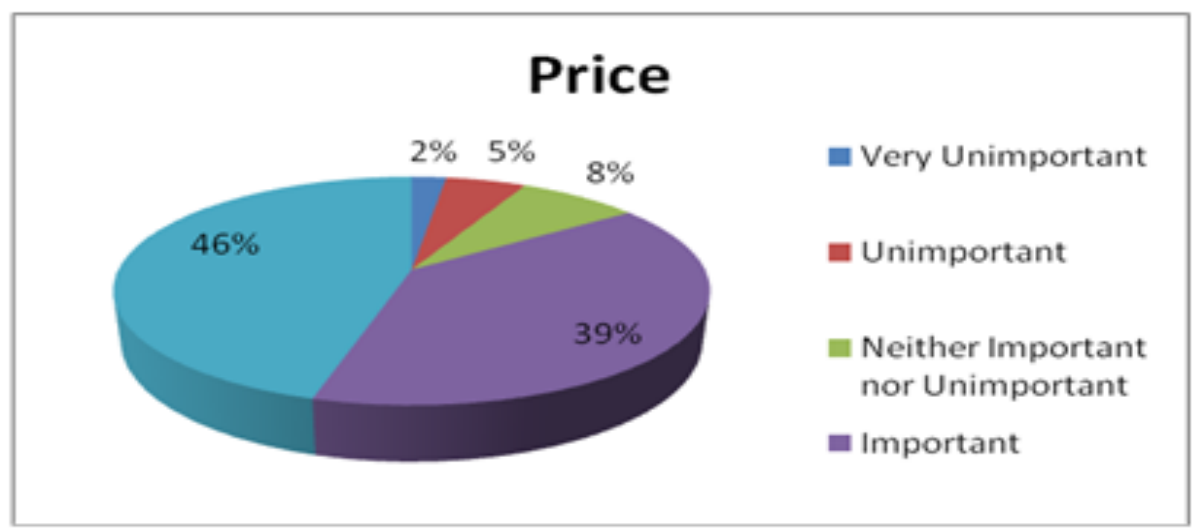

Figure 2: Priority Level on Price

Price of a product has a very significant effect on consumer behavior. It's considered to be one of the most influential decision drivers. $45.52 \%$ of respondents of this research point out that price are very important while $39.18 \%$ of them think it's important. The mean value 4.2052 suggests that price is an important driver in case of purchasing branded product. The standard deviation of 0.05812 also shows that the perception of the respondents is not scattered about this matter.

\section{Availability:}

Product availability has the power to trigger consumer's intension of buying. Marketers have spent significant effort and monetary resources on keeping products continuously available on shelves (Conlon and Mortimer 2009; Stayinfront 2011) and have considered product 
availability as a central feature in triggering sales (Hausman and Siekpe 2009; Jamieson and Bass 1989; Lee et al. 2008; Moon, Chadee and Tikoo 2008; Park 2003).Our research identify that availability of product is important to the $54.48 \%$ of total respondents, not only that $37.69 \%$ respondents consider it as very important item while purchasing personal care product.

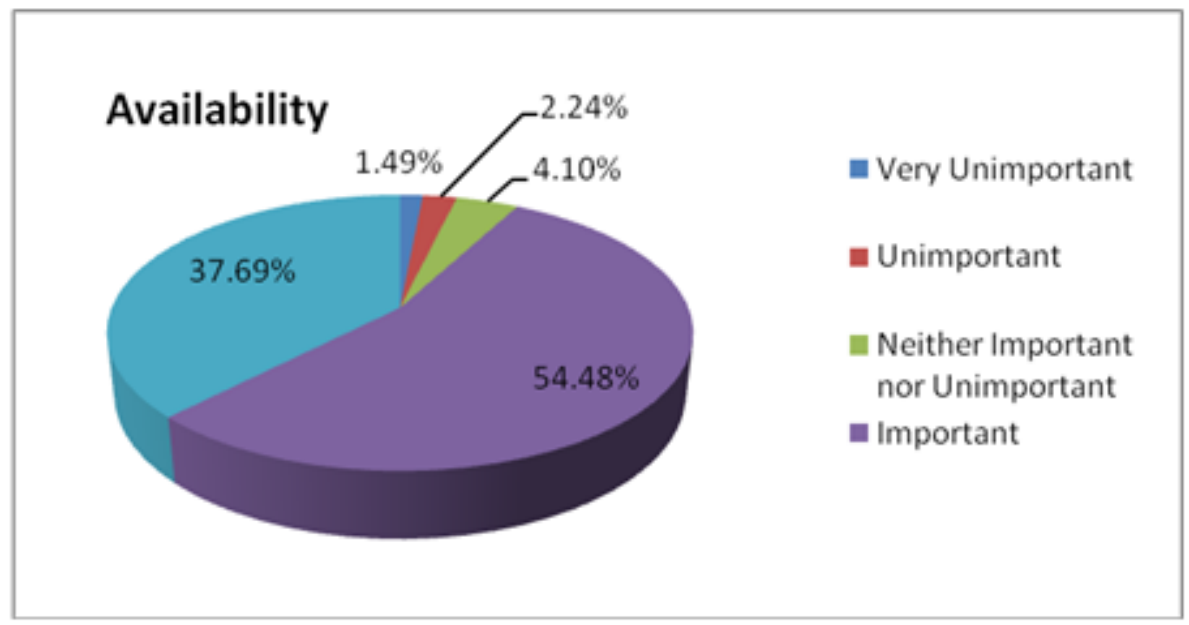

Figure 3: Priority Level on Availability

Mean value 4.2463 also depict the significance of availability and the standard deviation value 0.04665 indicates that this responses is not scattered.

\section{Country of Origin:}

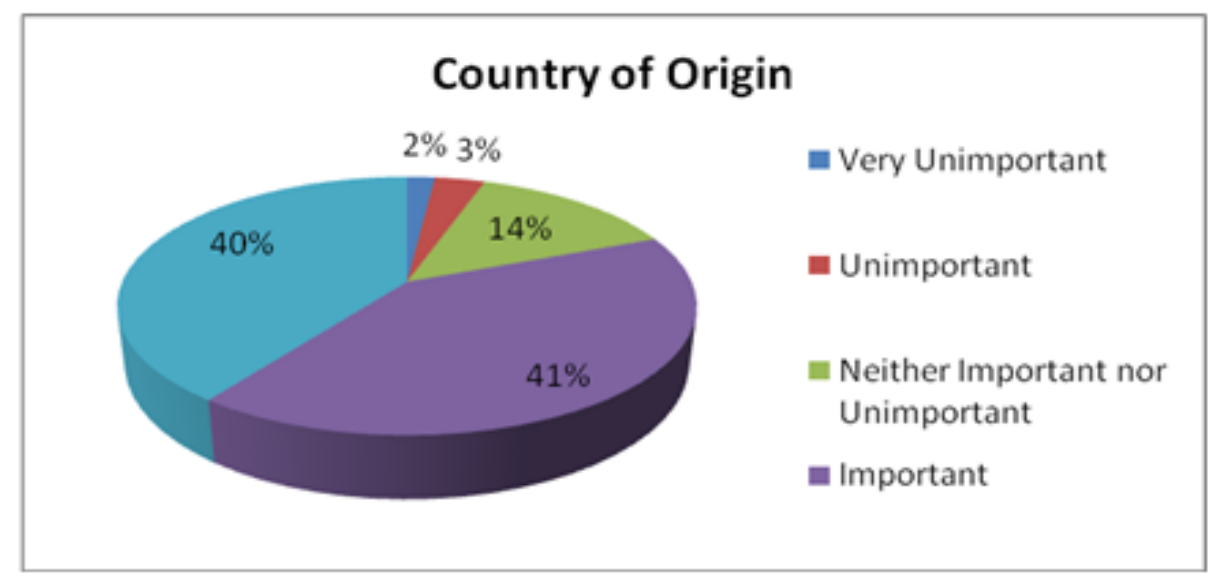

Figure 4: Priority Level on COO

Country of origin refers to the country at which a particular product is manufactured or produced. It can also be defined as any influence that the country of manufacturer has on a consumer's positive or negative perception of a product (Cateora \& Graham, 1999). Previous researches revealed that country-of-origin image play a significant role in consumer's perceptions towards products and brands from any given country (Hanzaee \& Khosrozadeh, 2011). Our observation towards this matter shows that $41.04 \%$ of total respondents find country of origin important whereas $39.93 \%$ of respondent find it very important. Though $13.81 \%$ respondents think that country of origin is neither important nor unimportant and $3.36 \%$ found 
it unimportant. A small portion of respondent (1.87\%) considers it as very unimportant. On the other hand the mean value 4.1381 strongly supported that country of origin is an important issue in case of making purchase decision and standard deviation 0.05543 also demonstrate that observation is not spread about the mean.

\section{Advertisement:}

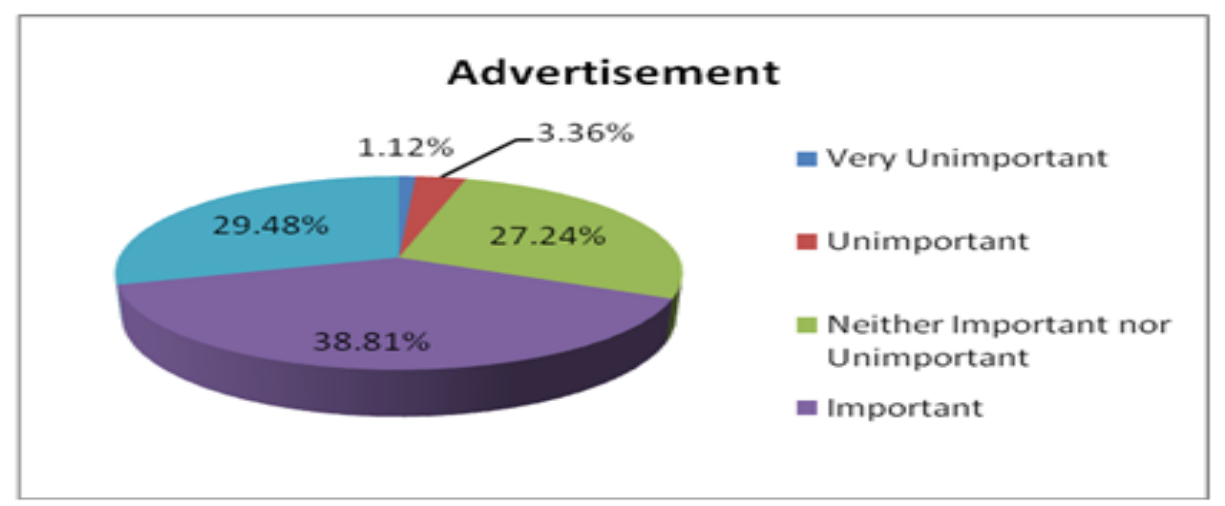

Figure 5: Priority Level on Advertisement

Companies use advertising to establish a basic awareness of the product or service in the mind of the potential customer and to build up knowledge about it (Morden, 1991). Advertising is happened to be a very crucial promotional tool that persuades potential consumers to make ultimate purchase decision. In this study respondents were asked about their perception towards advertising as a decision driver. $29.48 \%$ of respondents indicate it as very important and $38.81 \%$ specify it as important. But $27.24 \%$ point out advertising as neither important nor unimportant. According to $3.36 \%$ of respondents it's unimportant while $1.12 \%$ point out it as very unimportant. Our mean value 3.9216 also supports the fact that advertising has some diverse impact on Bangladeshi consumers while making purchase decision. The value of standard deviation .05460 shows that responses' regarding this matter is not too much scattered from mean.

\section{Part C: Level of Agreement}

\section{Customer's priority level for international brand while using or purchasing toiletries products:}

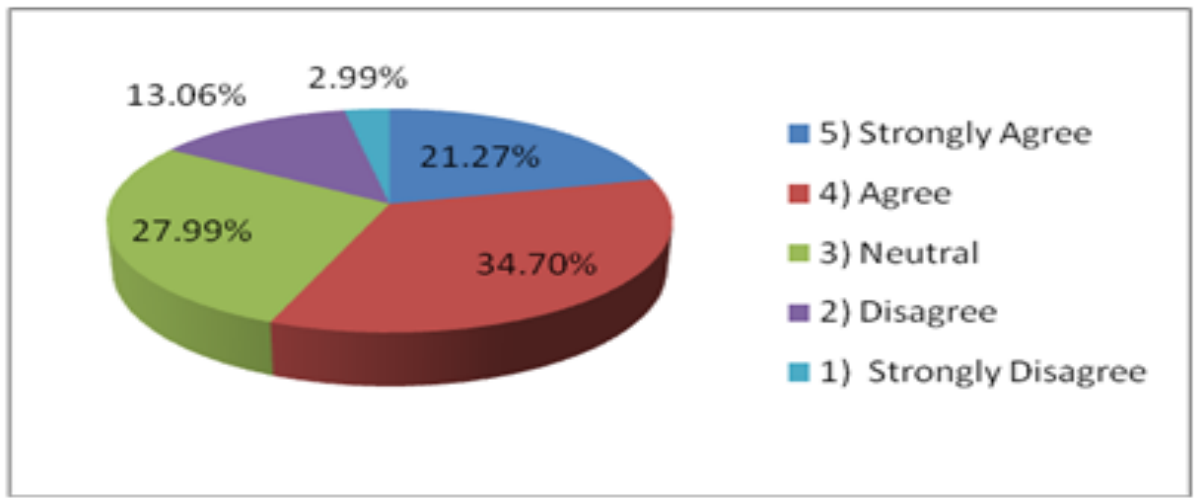

Figure 6: Customer's Perception toward International Brand

Purchasing goods more than $50 \%$ people of our study emphasis on international brand while only $15 \%$ more or less have no brand choice criteria. The mean value 3.58 indicate that people 
prefer international brand especially the names, fame, logo always have a positive impact on the people to use or purchase any product and the standard deviation (0.064)support the validity of the observation. Using foreign brands act as a defense mechanism for customers.

Brand equity has a positive influence on market power (Farquhar 1989), on consumers' willingness to pay premium prices (Keller 1993, Wedemeyer et.al.204)) and on the company's market share (Aaker 1996, Baldauf/Cravens/binder 2003).

\section{Customer prefer international brand because of its better quality than local brand:}

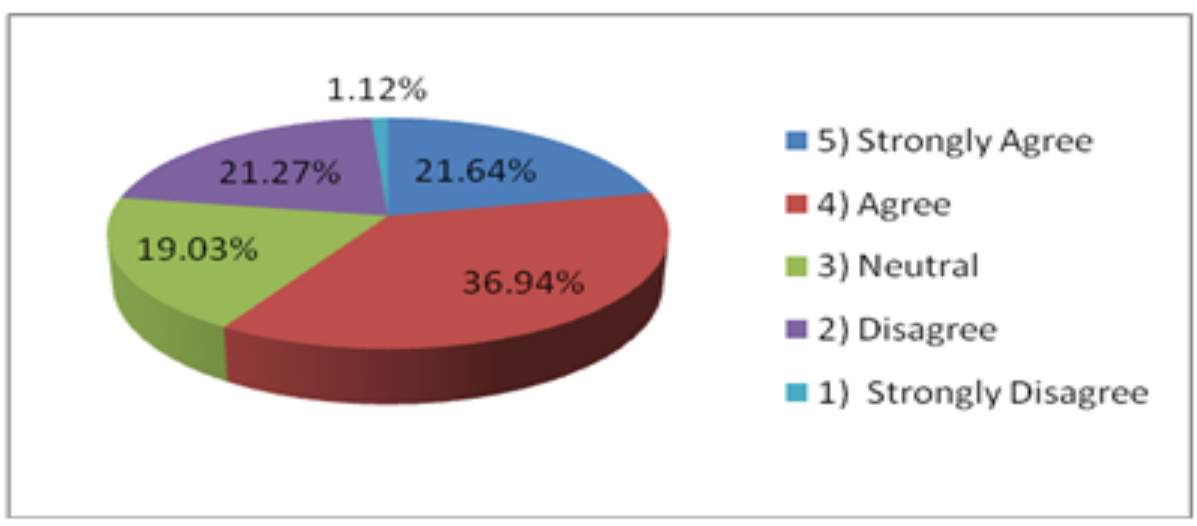

Figure 7: Customer's Perception of quality toward International Brand

To satisfy customer need quality is one of the major characteristics of a product or service that stands as a "fitness for use". In our study more than 58\% respondents prefer international brand because of quality as they put less confidence on local technology. On the other side $19.03 \%$ only focus on quality regardless local or foreign brand. A 3.56 mean value and standard deviation 0.066 support the statement that people prefer international brand because of its better quality than local brand.

\section{"Country of origin "or "origin of product" influenced customer to use international branded product:}

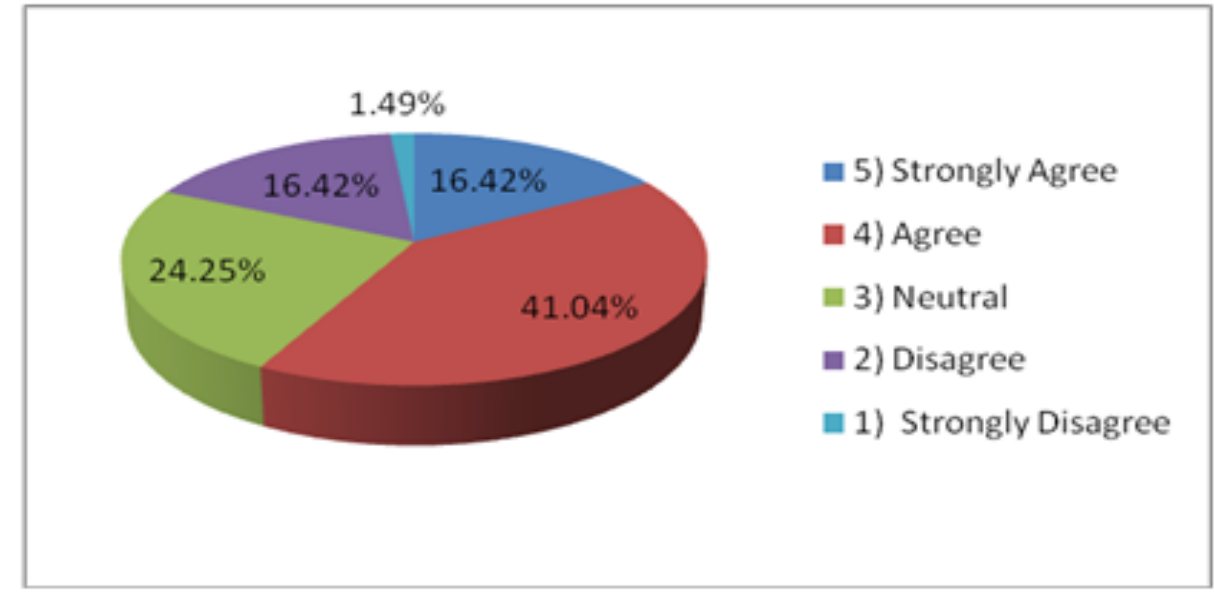

Figure 8: Customer's Perception of origin of product toward International Brand

Generally Bangladeshi people feel safe to purchase foreign branded electronic products because the performances of the products depend on the originality whereas different countries have expertise to make different products. Same perception happens while purchasing 
cosmetics products people especially girls or women are more dependent on foreign brand because they think. Women focus more conscious about country of origin while purchasing cream, body lotion, shampoo, hair oil and other kind of women skin sensitive cosmetic products.

Only $17.91 \%$ of our respondents did not put much importance on COO in case of buying products while $57.46 \%$ put more importance on COO and only $24.25 \%$ have their neutral opinion regarding this matter. The mean value (3.53) suggests that foreign made product influences the user more than local brand product where the standard deviation 0.06 indicates that the observations are not widely scattered about the mean.

Offering same price, international brand have more acceptance than local brand:

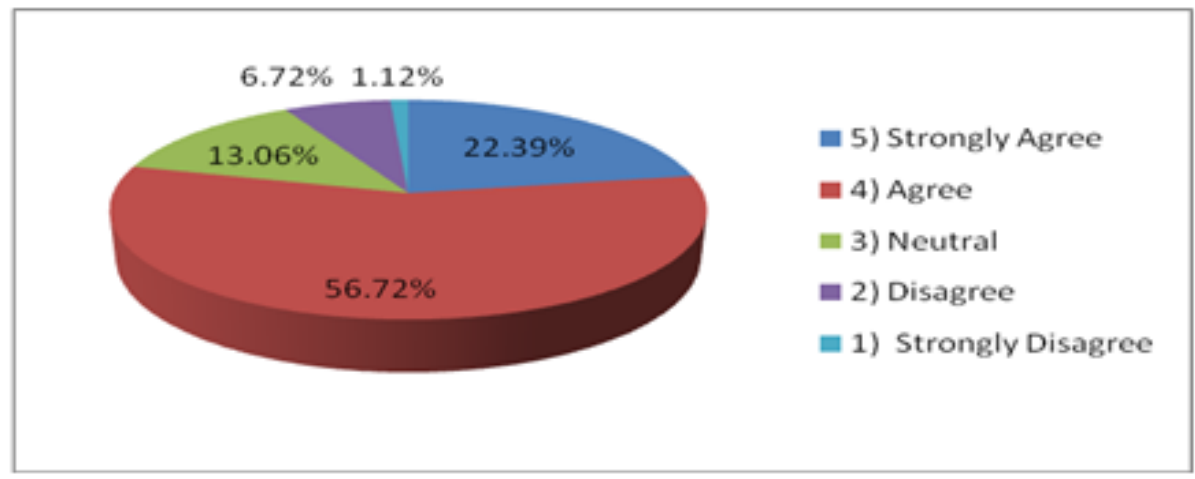

Figure 9: Customer's Perception of price consideration toward International Brand

Surprisingly it is true that customer mind plays a psychological game with customer about product price. Customer at the same time prefer foreign brand because of low price and also avoid local brand because of low price. Availability of factor of production of foreign brands leads low cost that may offer a reasonable price in the market while local brand offer high price because of high cost of productions. Knowing the fact people purchase international brand that indicates a low ethnocentrism of customer towards the country. From our study only $7.84 \%$ customer disagree regarding these matters.

\section{Consumption of international brand enhance customer's social image:}

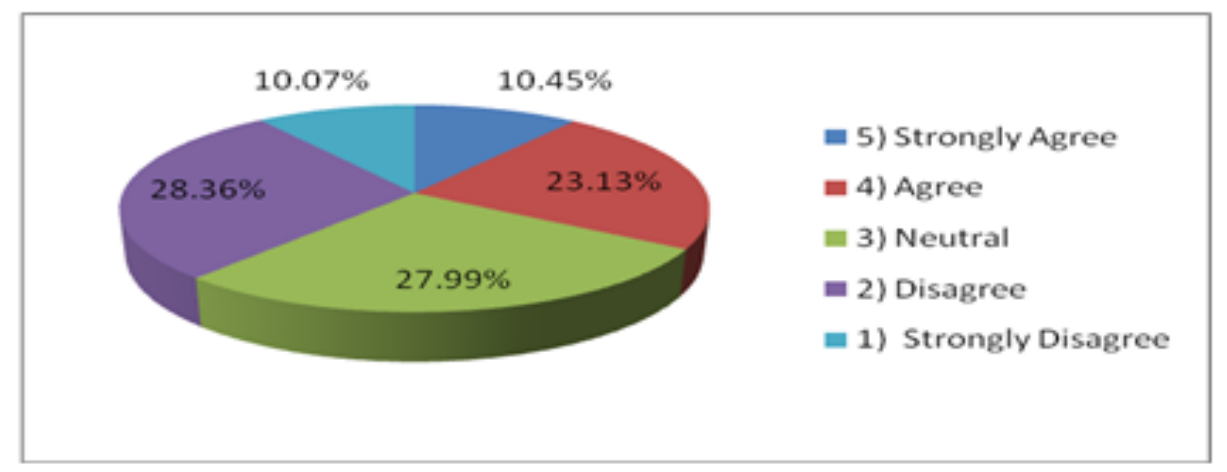

Figure 10: Customer's Perception of social image toward International Brand

Show off is a common tendency in this modern time. People prefer to express their social status through using foreign made product that indicates that they live a higher standard of life. 
But a mean value of 2.95 and standard deviation of 0.07 reveals that people put less importance on foreign brand to expose their social image because more than $38.43 \%$ customer disagree about this issue whereas only $27.99 \%$ customer have no positive or negative opinion regard this issue.

\section{Customer prefer international brand due to low availability of local product:}

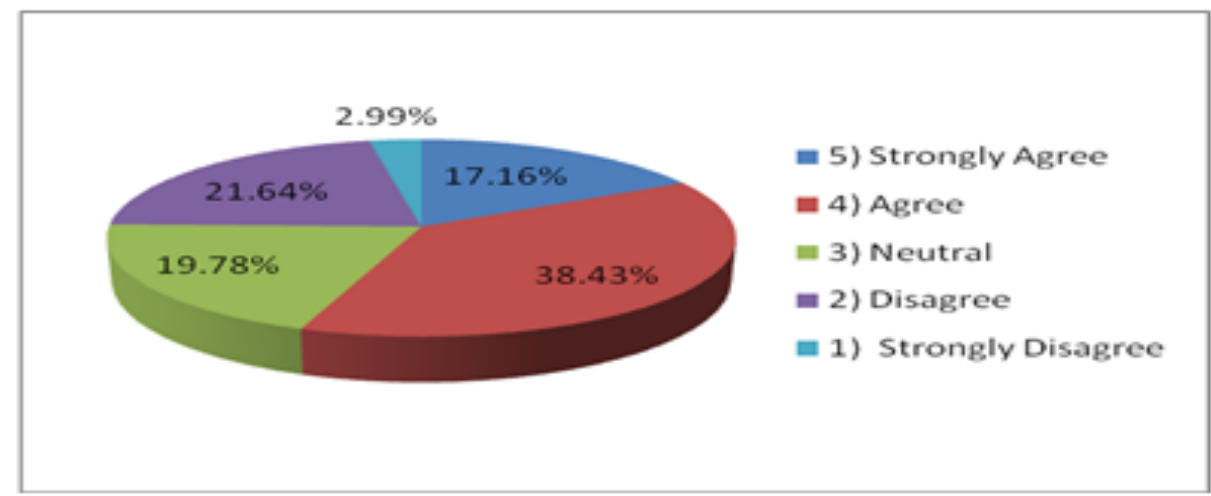

Figure 11: Customer's Perception of availability criteria toward International Brand

Although it is said that people safe free to use foreign brand over local brand but there is a observation that low availability of local brand give the scope to the foreign brand to expand market share. Although 56\% respondents agree or more ever we say strongly agree that people prefer international brand due to low availability of local product and a mean value of 3.45 also supported this statement but from our previous observation it is clearly reveals that people prefer foreign brand because of their perception of high quality, sensitive price range of international brand.

\section{Advertising and promotional activities influences customer to choose international brand over local brand:}

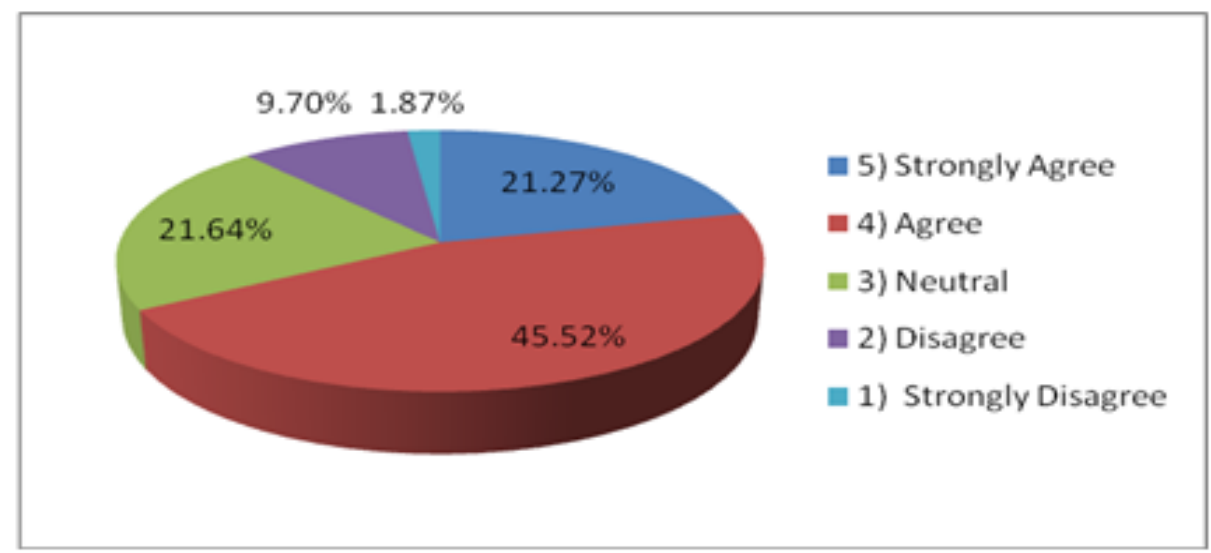

Figure 12: Customer's Perception of Advertising and promotional activities toward International Brand

From 268 respondents $45.52 \%$ agree and $21.2 \%$ strongly agree that different kinds of promotional activities influence respondent to choose international brand over local brand. Now a day's product placement is everywhere and foreign brand product capture the TV channel and mass media tremendously where local brand abaft from this competition. The 
mean value 3.73 supports that our observation is right that means customer's perception toward international brand influenced by different advertisement and promotional activities adopted by the foreign companies.

\section{CONCLUSION}

In response of using personal care products such as soap, washing powder or detergent, toothpaste, oil, shampoo etc. maximum time in maximum products more than $90 \%$ customer shows their purchasing behavior towards international brand. It is quite good that people lead a standard life where they enjoy the quality products within their purchasing power. But it is also true that using more foreign products can create a tough market place for local companies that damage the total economic system in future. To remedy these problems government and local marketers should take some strategies that will help the country to protect local industries and increase the level of job opportunities. To ensuring the growth of manufacturing sector, the manufacturer should be innovative in packaging, color, and fragrance when trying to appeal to customers.

To build customer Perception toward goods or services different marketing strategy such as Retail strategy, Shelf position and amount of shelf space, Brand name and Logo development, Media strategy, Advertising, and Packaging design, Developing warning labels and posters plays the significant role( Hawkins at al. 2011).

Our analysis discloses that quality is the item getting major importance while consumer purchase personal care product. Being a citizen of a developing country like Bangladesh, they are also concerned about the price and availability of the product. It's quite normal that high quality product comes with high price and sometimes it's hard for the mass people of Bangladesh to afford such products. As a result price acts as an important item for them while purchasing personal care product.

Another fact is even if people are ready to purchase pricy quality product, it needs to be available for them. So, most of the respondents consider availability as an important item.

As the global market is mounting rapidly, consumers are now much more conscious about the country in which a particular product has originated. It has both positive and negative impact on product as well as customers perception. In this study most of the customers also feel alike about this fact and put importance on country of origin.

By analyzing the responses of the consumers we get a mixed reaction about the item advertising. Where some respondents feel it is important or very important, there is also a portion of them who consider advertising as neither important nor unimportant.

We conducted our research on Rajshahi city which is famously known as "City of Education". Economy of Rajshahi city is largely enriched by the students gathered from different corners of the country for educational purpose. So it is quite normal that most of our respondents are students who in fact, now -a- days, are very mindful about their looks and styles as well as personal care product. Another reality about today's students is their craze for social media and it is undeniable that social media has been turned out to be one of the largest means of communication and knowledge. Through various social media platforms it becomes very easy for the students to know about the name, quality and price of the internationally branded products. Such information's enable them to compare international brand personal care product with local brand and also shape their perception while purchasing personal care decision.

In many developed countries such as the United Kingdom, Germany, France, Italy etc ,local brand perception is comparatively higher than international brand in case of brand awareness, brand image, trustworthiness brand value because of customer perception toward local brand 
as more "down to earth" than foreign brand . So Further analysis must examine in a bigger sample involving a wider geographical area which will help the marketer to analysis the need of customers, setting the proper pricing strategy to compete with foreign brand and facilitated the concerning body to develop the necessary strategy to influence the customer for using local brand.

\section{References}

Batra, R., Ramaswamy, V., Alden D.L., Steenkamp, J.E. M., S. Ramachander,(2000) Effects of Brand Local and Nonlocal Origin on Consumer Attitudes in Developing Countries, JOURNAL OF CONSUMER PSYCHOLOGY, 9(2), 83-95

Cateora, P. R., and Graham, J.L. (1999). International Marketing. (1st Ed), McGraw-Hill, Boston, MA

Conlon, C. T., and Mortimer, J. H., (2009). "Demand estimation under incomplete product availability," NBER Working Paper No. W14315.

Hanzaee, K.H., and Khosrozadeh, S. (2011). The Effect of the Country-of-origin Image, Product Knowledge and Product Involvement on Information Search and Purchase Intention. Middle-East Journal of Scientific, 8(3), 625-636.

Haque1, A., Anwar,N., Yasmin,F., Abdullah Sarwar,A., Ibrahim,Z., and Abdul Momen A.,(2015), Purchase Intention of Foreign Products:A Study on Bangladeshi Consumer Perspective, SAGE Open · June 2015,DOI: $10.1177 / 2158244015592680$

Hausman, A., \& Siekpe, J. (2009). The effect of web interface features on consumer online purchase intentions. Journal of Business Research, 62(1), 5-13.

Jamieson, L. F., \& Bass, F. M. (1989). Adjusting stated intention measures to predict trial purchase of new products: A comparison of models and methods. Journal of Marketing Research, 26(3), 336-345.

Hawkings, D.I., Mothersbaugh, D.L., Mookerjee.,(2011), Consumer behavior-building marketing strategy, Tata McGraw Hill Education Private Limited.

Islam, R., Perveen R., Islam, S.A.M., Ahmed, B.,(2014), Factors Affecting Consumers' Purchasing Decision Of Toiletries Products: An Empirical Study on Square Toiletries In Khulna City, Journal of Business And Technology(Dhaka).

Islam, M.S., and Akhtar,S., Role of Brands on Consumer's Buying Behavior in Bangladesh: a Study on Fashion Cloth, European Journal of Business and Management, ISSN 2222-1905 (Paper) ISSN 2222-2839 (Online)Vol.5, No.12, 2013

Ismail. Z., Masood. S., Tawab. Z. M.,(2012), Factors Affecting Consumer Preference of International Brands over Local Brands, 2012 2nd International Conference on Social Science and Humanity, IPEDR vol.31 (2012) C (2012) IACSIT Press, Singapore.

Jeeyeon Ha and Keun Lee (2012),"An Integrative Consumer Behavior Model Involving Domestic/Foreign Products: a Literature Review and Future Research Direction", in AP - Asia-Pacific Advances in Consumer Research Volume 10, eds. , Duluth, MN :Association for Consumer Research, Pages: 211-223.

Karmoker,K., Haque, E., Uddin, R.,(2016), Determinants of Purchasing Non-Local Fast Moving Consumer Goods in Bangladesh: Evidence from Khulna City, Global Journal of Management and Business Research: E MarketingVolume 16 Issue 5 Version 1.0 Year 2016.

Kramolis J. and Drabkova M.,(2012), Types, Forms and Major Product Categories of Product Placement in the Czech Republic, Journal of Eastern Europe Research in Business \& Economics, Vol. 2012 (2012), Article ID 441984, 11 pages, DOI: 10.5171/2012.441984.

Madahi, A. and Sukati, I. (2012) The Effect of External Factors on Purchase Intention amongst Young Generation in Malaysia. International Business Research; Vol. 5, No. 8; 2012.

Md. Babu, S.H.,(2004), A STUDY ON CONSUMERS' PSYCHOLOGY ON MARKETING TOOLS, Philosophy and Progress: Vols. LV-LVI, January-June, July-December, 2014,ISSN 1607-2278 (Print), DOI: http://dx.doi.org/10.3329/pp.v55i1-2.26394

Mollah, S., Kim, M-H., Choudhury, M.M.,(2015),consumer attitude towards different shampoo brands:evidence from Bangladesh,world journal of social science,Vol. 5. No. 2, April-2015,Pp 81-89.

Moon, J., Chadee, D., \& Tikoo, S. (2008). Culture, product type, and price influences on consumer purchase intention to buy personalized products online. Journal of Business Research, 61(1), 31-41

Morden A.R. 1991. Elements of Marketing, London: D.P. Publication Ltd. 
Park, C. H. (2003). Identifying key factors affecting consumer purchase behavior in an online shopping context. International Journal of Retail and Distribution Management, 31(1), 16-29.

Roth K.P., Adamantios Diamantopoulos A., Montesinos A.M., Home Country Image, Country Brand Equity, and Consumers' Product Preferences: An Empirical Study, Management International Review · November 2008, DOI: 10.1007/s11575-008-0031-y

SAK ONKVISIT \& JOHN SHAW, (2007), International Marketing -Analysis and Strategy, Taylor \& Francis e-Library

Shafiq, R., Raza, I. and Zia ur Rehman, M. (2011), Analysis of the factors affecting customers' purchase intention: The mediating role of perceived value. African Journal of Business Management Vol. 5(26), pp. 10577-10585

SRIVASTAVA R.K., Shervani T.A., Fahey L., Marketing,(1999) Business Processes, and Shareholder Value: An Organizationally Embedded View of Marketing Activities and the Discipline of Marketing, Journal of Marketing,Vol. 63 (Special Issue 1999), 168-179

Zareei,A.,Ashtiani,P.G.,(2015),Consumer Perceptions Of Global And Local Brands,IndianJournal of Fundamental and Applied Life Science,ISSN:2231-6345,vol.5(SI),pp.4247-4255.

\section{Online Sources:}

(https://marketbusinessnews.com/financial-glossary/quality/).

(https://bizfluent.com/info-7905922-effect-price-consumer-buying-behavior.html).

\section{Appendix}

\section{Part B: Level of Importance}

Table 1: Quality

\begin{tabular}{|c|c|c|c|c|}
\hline Criteria & No. of Respondents & Percentage & Mean & SD \\
\hline Very Unimportant & 6 & $2.24 \%$ & \multirow{6}{*}{4.3321} & \multirow{6}{*}{0.04808} \\
\hline Unimportant & 3 & $1.12 \%$ & & \\
\hline Neither Important nor Unimportant & 8 & $2.99 \%$ & & \\
\hline Important & 130 & $48.51 \%$ & & \\
\hline Very Important & 121 & $45.15 \%$ & & \\
\hline Total & 268 & $100.00 \%$ & & \\
\hline
\end{tabular}

Table 2: Price

\begin{tabular}{|c|r|r|r|r|}
\hline Criteria & No. of Respondents & Percentage & Mean & SD \\
\hline Very Unimportant & 6 & $2.24 \%$ & & \\
\cline { 1 - 3 } Unimportant & 14 & $5.22 \%$ & \\
\cline { 1 - 3 } Neither Important nor Unimportant & 21 & \multirow{2}{*}{4.2052} & \multirow{2}{*}{0.05812} \\
\cline { 1 - 3 } Important & 105 & $39.18 \%$ & \\
\cline { 1 - 3 } Very Important & 122 & $45.52 \%$ & & \\
\cline { 1 - 3 } Total & 268 & $100.00 \%$ & & \\
\hline
\end{tabular}

Table3: Availability

\begin{tabular}{|c|r|r|r|r|}
\hline Criteria & No. of Respondents & Percentage & Mean & SD \\
\hline Very Unimportant & 4 & $1.49 \%$ & & \\
\cline { 1 - 3 } Unimportant & 6 & $2.24 \%$ & & \\
\cline { 1 - 3 } Neither Important nor Unimportant & 11 & $4.10 \%$ & & \\
\cline { 1 - 3 } Important & 146 & $54.48 \%$ & \multirow{2}{*}{4.2463} & \multirow{2}{*}{0.0466} \\
\cline { 1 - 3 } Very Important & 101 & $100.00 \%$ & & \\
\hline Total & 268 & &
\end{tabular}


Table4: Country of Origin

\begin{tabular}{|c|c|c|c|c|}
\hline Criteria & No. of Respondents & Percentage & Mean & SD \\
\hline Very Unimportant & 5 & $1.87 \%$ & \multirow{6}{*}{4.1381} & \multirow{6}{*}{0.05543} \\
\hline Unimportant & 9 & $3.36 \%$ & & \\
\hline Neither Important nor Unimportant & 37 & $13.81 \%$ & & \\
\hline Important & 110 & $41.04 \%$ & & \\
\hline Very Important & 107 & $39.93 \%$ & & \\
\hline Total & 268 & $100.00 \%$ & & \\
\hline
\end{tabular}

Table 5: Advertisement

\begin{tabular}{|c|c|r|r|r|}
\hline Criteria & No. of Respondents & Percentage & Mean & SD \\
\hline Very Unimportant & 3 & $1.12 \%$ & & \\
\cline { 1 - 3 } Unimportant & 9 & $3.36 \%$ & & \\
\cline { 1 - 3 } Neither Important nor Unimportant & 73 & $27.24 \%$ & & \\
\cline { 1 - 3 } Important & 104 & $38.81 \%$ & \multirow{2}{*}{3.9216} & \multirow{2}{*}{.05460} \\
\cline { 1 - 3 } Very Important & 79 & $100.00 \%$ & & \\
\hline Total & 268 & & \\
\hline
\end{tabular}

\section{Part C: Level of Agreement}

Customer's priority level for international brand while using or purchasing toiletries products:

\begin{tabular}{|c|c|c|c|c|}
\hline Criteria & No. of Respondents & Percentage & Mean & SD \\
\hline 5) Strongly Agree & 57 & $21.27 \%$ & & \\
\hline 4) Agree & 93 & $34.70 \%$ & & \\
\hline 3) Neutral & 75 & $27.99 \%$ & \multirow{3}{*}{3.58} & \\
2) Disagree & 35 & $13.06 \%$ & & \multirow{2}{*}{0.064} \\
\cline { 1 - 3 } 1) Strongly Disagree & 8 & $2.99 \%$ & & \\
\hline Total & 268 & $100.00 \%$ & & \\
\hline
\end{tabular}

Customer prefer international brand because of its better quality than local brand:

\begin{tabular}{|c|c|c|c|c|}
\hline Criteria & No. of Respondents & Percentage & Mean & SD \\
\hline 5) Strongly Agree & 58 & $21.64 \%$ & & \\
\hline 4) Agree & 99 & $36.94 \%$ & & \\
\hline 3) Neutral & 51 & $19.03 \%$ & & \multirow{2}{*}{3.56} \\
2) Disagree & 57 & $21.27 \%$ & \\
1) Strongly Disagree & 3 & $1.12 \%$ & & \\
\hline Total & 268 & $100.00 \%$ & & \\
\hline
\end{tabular}

"Country of origin "or "origin of product" influenced customer to use international branded product.

\begin{tabular}{|c|c|c|c|c|}
\hline Criteria & No. of Respondents & Percentage & Mean & SD \\
\hline 5) Strongly Agree & 44 & $16.42 \%$ & & \\
\hline 4) Agree & 110 & $41.04 \%$ & & \\
\hline 3) Neutral & 65 & $24.25 \%$ & & \\
2) Disagree & 44 & $16.42 \%$ & \multirow{2}{*}{3.53} & \multirow{2}{*}{0.06} \\
\hline 1) Strongly Disagree & 4 & $1.49 \%$ & & \\
\hline Total & 268 & $100.00 \%$ & & \\
\hline
\end{tabular}


Offering same price, international brand have more acceptance than local brand:

\begin{tabular}{|c|c|c|c|c|}
\hline Criteria & No. of Respondents & Percentage & Mean & SD \\
\hline 5) Strongly Agree & 60 & $22.39 \%$ & & \\
\hline 4) Agree & 152 & $56.72 \%$ & \\
\cline { 1 - 3 } 3) Neutral & 35 & $13.06 \%$ & \multirow{2}{*}{3.92} & \\
\hline 2) Disagree & 18 & $6.72 \%$ & & \multirow{2}{*}{0.051} \\
\hline $\begin{array}{c}\text { Strongly Disa- } \\
\text { gree }\end{array}$ & 3 & $1.12 \%$ & & \\
\hline Total & 268 & $100.00 \%$ & \\
\hline
\end{tabular}

Consumption of international brand enhance customer's social image

\begin{tabular}{|c|c|c|c|c|}
\hline Criteria & No. of Respondents & Percentage & Mean & SD \\
\hline 5) Strongly Agree & 28 & $10.45 \%$ & & \\
\cline { 1 - 3 } 4) Agree & 62 & $23.13 \%$ & & \\
\cline { 1 - 3 } 3) Neutral & 75 & $27.99 \%$ & & \\
\cline { 1 - 3 } 2) Disagree & 76 & $28.36 \%$ & \\
\cline { 1 - 3 } 1) Strongly Disagree & 27 & $10.07 \%$ & \\
\cline { 1 - 3 } Total & 268 & $100.00 \%$ & & \multirow{2}{*}{0.07} \\
\hline
\end{tabular}

Customer prefer international brand due to low availability of local product:

\begin{tabular}{|c|c|c|c|c|}
\hline Criteria & No. of Respondents & Percentage & Mean & SD \\
\hline 5) Strongly Agree & 46 & $17.16 \%$ & \multirow{3}{*}{3.45} & \\
\hline 4) Agree & 103 & $38.43 \%$ & \multirow{2}{*}{0.067} \\
\hline 3) Neutral & 53 & $19.78 \%$ & & \\
\hline 2) Disagree & 58 & $21.64 \%$ & & \\
\hline 1) Strongly Disagree & 8 & $2.99 \%$ & & \\
\hline Total & 268 & $100.00 \%$ & & \\
\hline
\end{tabular}

Advertising and promotional activities influences customer to choose international brand over local brand. :

\begin{tabular}{|c|c|c|c|c|}
\hline Criteria & No. of Respondents & Percentage & Mean & SD \\
\hline 5) Strongly Agree & 57 & $21.27 \%$ & & \multirow{3}{*}{0.058} \\
\hline 4) Agree & 122 & $45.52 \%$ & \multirow{3}{*}{3.73} & \\
\hline 3) Neutral & 58 & $21.64 \%$ & & \\
\hline 2) Disagree & 26 & $9.70 \%$ & & \\
\hline 1) Strongly Disagree & 5 & $1.87 \%$ & & \\
\hline Total & 268 & $100.00 \%$ & & \\
\hline
\end{tabular}

